\title{
Platelet Serotonergic Markers as Endophenotypes for Obsessive-Compulsive Disorder
}

\author{
Richard Delorme*,1,2, Catalina Betancur', Jacques Callebert ${ }^{3}$, Nadia Chabane ${ }^{1,2}$, Jean-Louis Laplanche ${ }^{3}$, \\ Marie-Christine Mouren-Simeoni ${ }^{2}$, Jean-Marie Launay ${ }^{3}$ and Marion Leboyer ${ }^{1,4}$ \\ 'INSERM U 513, Faculté de Médecine, Créteil, France; '2Service de Psychopathologie de l'Enfant et de l'Adolescent, Hôpital Robert Debré, \\ Assistance Publique-Hôpitaux de Paris, Paris, France; ${ }^{3}$ Service de Biochimie, Hôpital Lariboisière, Paris, France; ${ }^{4}$ Service de Psychiatrie, Hôpital \\ Henri Mondor et Albert Chenevier, Assistance Publique-Hôpitaux de Paris, Créteil, France
}

\begin{abstract}
Although compelling evidence has shown that obsessive-compulsive disorder (OCD) has a strong genetic component, its genetic basis remains to be elucidated. Identifying biological abnormalities in nonaffected relatives is one of the strategies advocated to isolate genetic vulnerability factors in complex disorders. Since peripheral serotonergic disturbances are frequently observed in OCD patients, the aim of this study was to investigate if they could represent endophenotypes, by searching for similar abnormalities in the unaffected parents of OCD patients. We assessed whole blood serotonin (5-HT) concentration, platelet 5-HT transporter (5-HTT) and 5-HT $2 \mathrm{~A}$ receptorbinding characteristics, and platelet inositol trisphosphate $\left(\mathrm{IP}_{3}\right)$ content in a sample of $\mathrm{OCD}$ probands $(n=48)$ and their unaffected parents $(n=65)$, and compared them with sex- and age-matched controls $(n=1 \mid 3)$. Lower whole blood 5-HT concentration, fewer platelet 5-HTT-binding sites, and higher platelet $\mathrm{IP}_{3}$ content were found in $\mathrm{OCD}$ probands and their unaffected parents compared to controls. Whole blood 5 -HT concentration showed a strong correlation within families $(p<0.00 \mathrm{I})$. The only parameter that appeared to discriminate affected and unaffected subjects was $5-\mathrm{HT}_{2 \mathrm{~A}}$ receptor-binding characteristics, with increased receptor number and affinity in parents and no change in OCD probands. The presence of peripheral serotonergic abnormalities in OCD patients and their unaffected parents supports a familial origin of these disturbances. These alterations may serve as endophenotypic markers in OCD, and could contribute to the study of the biological mechanisms and genetic underpinnings of the disorder.

Neuropsychopharmacology (2005) 30, I539-1547, advance online publication, I I May 2005; I0.1038/sj.npp. I 300752
\end{abstract}

Keywords: serotonin; serotonin transporter; 5-HT2A receptor; binding; inositol triphosphate; intrafamilial correlation

\section{INTRODUCTION}

Obsessive-compulsive disorder (OCD) is a severe, chronic neuropsychiatric illness, characterized by recurrent, distressing, unwanted thoughts (obsessions) and repetitive, ritualistic behaviors (compulsions). OCD is a common disorder, affecting between 2 and $3 \%$ of the population (Weissman et al, 1994). Although the precise etiology of the disorder remains unknown, the results of twin studies (Jonnal et al, 2000), family genetic studies (Nestadt et al, 2000b; Pauls et al, 1995), and segregation analyses (Alsobrook et al, 1999; Nestadt et al, 2000a) have provided compelling evidence that OCD has a strong genetic component. However, like other major psychiatric dis-

\footnotetext{
*Correspondence: Dr R Delorme, INSERM U5I3, Faculté de Médecine, 8 rue du Général Sarrail, 94010 Créteil cedex, France, Tel: +33 | 498135 |4, Fax: + 33 | 49813685 ,

E-mail: delorme@im3.inserm.fr

Received 30 July 2004; revised 17 February 2005; accepted 3 March 2005

Online publication: 31 March 2005 at http://www.acnp.org/citations/ Npp033 I05040348/default.pdf
}

orders, OCD fails to follow Mendelian patterns of inheritance and is considered as a complex genetic disorder.

The first genome scan for OCD performed in a small number of families found suggestive evidence for linkage to chromosome 9p24 (Hanna et al, 2002) and this finding was recently replicated in an independent data set (Willour et al, 2004). In addition, several theoretically relevant functional candidate genes have been examined in OCD, but no susceptibility genes have yet been identified with certainty. The difficulty in identifying the responsible genes may be the consequence of the clinical and genetic heterogeneity of the disorder. The endophenotype approach is one of the strategies advocated to identify relevant phenotypes in complex disorders (Leboyer et al, 1998). Endophenotypes are variables that correlate with a given disease, are usually subclinical, involve fewer genes than those involved in the disease syndrome itself, and may thus serve to better define the disorder and could assist in the identification of genes conferring vulnerability to the disorder (Gottesman and Gould, 2003). To meet the criteria for an endophenotype, a marker must be present in affected individuals, it should be heritable and cosegregate with the illness, it should be state-independent (ie, manifests in an individual 
whether or not the illness is active), and must be found among unaffected relatives of patients at a higher rate than in the general population (Leboyer, 2003; Gottesman and Gould, 2003).

The selective response to drugs that potently inhibit the reuptake of serotonin (5-hydroxytryptamine, 5-HT) has been amply demonstrated in OCD and was at the origin of the 5-HT hypothesis concerning the pathophysiology of the disorder (Barr et al, 1992). The 5-HT transporter (5-HTT) is a critical component of the serotonergic system and the principal site of action of the widely prescribed 5-HT reuptake inhibitors (Blier and de Montigny, 1999). Untreated OCD patients exhibit either reduced (YaryuraTobias et al, 1979) or normal (Cath et al, 2001; Delorme et al, 2004; Flament et al, 1987; Hanna et al, 1991; Insel and Winslow, 1992) whole blood or platelet 5-HT levels, whereas the binding capacity $\left(B_{\max }\right)$ of the platelet 5 -HTT is consistently reduced, both for $\left[{ }^{3} \mathrm{H}\right]$-paroxetine (Marazziti et al, 1999; Sallee et al, 1996) and $\left[{ }^{3} \mathrm{H}\right]$-imipramine (Bastani et al, 1991; Marazziti et al, 1992; Marazziti et al, 1997; Weizman et al, 1992). Treatment with 5-HT reuptake inhibitors lowers whole blood 5-HT concentration and further decreases the number of 5-HTT-binding sites, and the magnitude of the decrease is correlated with clinical improvement (Black et al, 1990; Delorme et al, 2004; Flament et al, 1987; Hanna et al, 1993).

The platelet $5-\mathrm{HT}_{2 \mathrm{~A}}$ receptor-binding characteristics and inositol 1,4,5 triphosphate $\left(\mathrm{IP}_{3}\right)$ content may also be relevant as markers of vulnerability in OCD. Pharmacological studies suggest the implication of $5-\mathrm{HT}_{2 \mathrm{~A}}$ receptors in the pathophysiology of $\mathrm{OCD}$, since risperidone, a $5-\mathrm{HT}_{2} /$ $\mathrm{D}_{2}$ receptor antagonist, appears to potentiate the efficiency of 5-HT reuptake inhibitors in resistant OCD patients through an effect mediated by $5-\mathrm{HT}_{2 \mathrm{~A}}$ receptors (Marek et al, 2003; McDougle et al, 2000). Furthermore, we recently reported elevated platelet $\mathrm{IP}_{3}$ content without modification of the $B_{\max }$ or the $K_{\mathrm{d}}$ of the platelet $5-\mathrm{HT}_{2 \mathrm{~A}}$ receptor in drugfree OCD patients, suggesting an increase in the intrinsic activity of $5-\mathrm{HT}_{2 \mathrm{~A}}$ receptors resulting in overstimulation of the platelet phosphoinositide signaling system (Delorme et al, 2004).

The aims of this study were to confirm the presence of peripheral serotonergic disturbances in a sample of OCD probands and to search for the presence of similar abnormalities in their unaffected parents. The parameters investigated were whole blood 5-HT content, platelet 5-HTT and $5-\mathrm{HT}_{2 \mathrm{~A}}$ receptor-binding characteristics, and platelet $\mathrm{IP}_{3}$ content. Such serotonergic disturbances observed in OCD probands and their unaffected relatives would suggest that they might be endophenotypic markers of the vulnerability to OCD, and could be used as alternative biological phenotypes in genetic studies.

\section{PATIENTS AND METHODS}

\section{Subjects}

A total of 48 probands suffering from OCD according to DSM-IV criteria were recruited from two university hospital psychiatric departments for children (Hôpital Robert Debré, Paris) and adults (Hôpital Albert Chenevier, Créteil). The clinical and demographic characteristics of OCD probands
Table I Clinical and Demographic Characteristics of OCD Probands and Their Unaffected Parents

\begin{tabular}{|c|c|c|}
\hline & $\begin{array}{c}\text { Probands } \\
(n=48)\end{array}$ & $\begin{array}{c}\text { Unaffected } \\
\text { parents }(n=65)\end{array}$ \\
\hline Male/female & $33 / 15$ & $29 / 36$ \\
\hline Age at interview (years) ${ }^{\mathrm{a}}$ & $18.7 \pm 9.9$ & $48.9 \pm 9.8$ \\
\hline Age at onset of OCD (years) ${ }^{a}$ & $11.3 \pm 11.6$ & - \\
\hline $\begin{array}{l}\text { No. of drug-free/treated patients at } \\
\text { inclusion }\end{array}$ & $33 / 15$ & $65 / 0$ \\
\hline \multicolumn{3}{|l|}{ Y-BOCS total score } \\
\hline Drug-free patients ${ }^{\mathrm{a}}$ & $27.1 \pm 5.7$ & - \\
\hline Treated patients $^{\mathrm{a}}$ & $20.3 \pm 6.4$ & - \\
\hline \multicolumn{3}{|l|}{ Y-BOCS checklist_-main categories } \\
\hline \multicolumn{3}{|l|}{ Obsessions (\%) } \\
\hline Aggressive & 68 & - \\
\hline Contamination & 68 & - \\
\hline Sexual & 24 & - \\
\hline Hoarding & 37 & - \\
\hline Religious & 50 & - \\
\hline Symmetric/ordering & 63 & - \\
\hline Somatic & 52 & - \\
\hline \multicolumn{3}{|l|}{ Compulsions (\%) } \\
\hline Washing & 76 & - \\
\hline Checking & 81 & - \\
\hline Repeating & 73 & - \\
\hline Counting & 42 & - \\
\hline Ordering & 68 & - \\
\hline Hoarding & 30 & - \\
\hline
\end{tabular}

a Mean \pm SD. Y-BOCS, Yale-Brown Obsessive Compulsive Scale.

are shown in Table 1. Lifetime psychiatric history was evaluated during a direct interview, either with the Diagnostic Interview for Genetic Studies (DIGS) (Nurnberger et al, 1994) for patients over the age of 17 years, or with the Kiddie Schedule for Affective Disorders and Schizophrenia-Epidemiologic version (K-SADS-e) (Orvaschel et al, 1982) for those aged under 17 years. The symptom checklist and ordinal scales of the Yale-Brown Obsessive Compulsive Scale (Y-BOCS, Goodman et al, 1989) were used to evaluate the severity and the diversity of OC symptoms at the time of inclusion (Table 1). To be included in the study, patients had to have OCD as their main disorder and no associated depression at the time of inclusion. However, some patients had lifetime comorbid disorders, including anxious disorders $(n=19)$, Tourette's syndrome $(n=17)$, attention deficit hyperactivity disorder $(n=15)$, eating disorders $(n=3)$, and alcohol dependence $(n=1)$. In total, 15 patients were receiving 5-HT reuptake inhibitors at the time of assessment, while the remaining 33 patients received no medication at the time of assessment and had been drugfree for at least 8 weeks. Drug treatment was limited to a monotherapy and had been introduced for more than 12 weeks at the time of blood sampling. The choice of 5-HT reuptake inhibitors and the dose were left to the clinician. Among the 15 treated subjects included, eight were treated 
with sertraline $(106.3 \pm 49.7 \mathrm{mg} /$ day $)$, three with paroxetine $(26.7 \pm 11.7 \mathrm{mg} /$ day $)$, two with fluoxetine $(100 \mathrm{mg} /$ day $)$, and two with fluvoxamine $(35 \pm 7.07 \mathrm{mg} /$ day).

In addition, 65 parents of OCD probands were also included in the study (Table 1). All parents were directly interviewed with the DIGS. Parents found to have a lifetime history of OCD, a mood disorder at the time of the interview, or who had taken a psychotropic treatment during the past 8 weeks were excluded from the study.

Controls $(n=113)$, sex- and age-matched with probands and relatives, were healthy volunteers recruited among blood donors and orthopedic patients at the Lariboisière Hospital in Paris. Control subjects were receiving no psychotropic treatment at the time of assessment and had been drug-free for at least 8 weeks. All patients, parents, and controls were Caucasian. The local Research Ethics Board approved the study protocol. Written informed consent was obtained from all participating subjects. If the proband was under 18 years old, the proband's consent and written parental consent was obtained.

\section{Blood Sampling}

All participants were asked to follow a diet poor in tryptophan and 5-HT during 2 days before the blood sampling. Blood samples $(7-10 \mathrm{ml})$ were collected in tubes containing EDTA between 0800 and 0100 hours. Then, $1 \mathrm{ml}$ of blood was immediately stored at $-80^{\circ} \mathrm{C}$ until used for the 5-HT assay. Platelet-rich plasma (PRP) was prepared from the rest of the sample within $2 \mathrm{~h}$ by centrifugation at $200 \mathrm{~g}$ for $15 \mathrm{~min}$ at room temperature. The PRP was collected and centrifuged at $2000 \mathrm{~g}\left(4^{\circ} \mathrm{C}, 15 \mathrm{~min}\right)$. Platelet pellets were stored at $-80^{\circ} \mathrm{C}$ until used.

\section{Biochemical Measurements}

Serotonin. Whole blood 5-HT concentration was determined by a radioenzymatic procedure as previously described (Matuchansky and Launay 1995).

Binding of $\left[{ }^{3} \mathrm{H}\right]$-imipramine, $\left[{ }^{3} \mathrm{H}\right]$-paroxetine, and $\left[{ }^{125} \mathrm{I}\right]$ $L S D$. Platelet membranes were prepared by lysing each platelet pellet hypotonically in $5 \mathrm{ml}$ of $5 \mathrm{mM}$ Tris- $\mathrm{HCl}, 5 \mathrm{mM}$ EDTA (pH 7.4). The samples were homogenized with a polytron and centrifuged twice at $20000 \mathrm{~g}, 4^{\circ} \mathrm{C}$, for $30 \mathrm{~min}$. The supernatant was discarded and the pellet was suspended in incubation buffer $(50 \mathrm{mM}$ Tris- $\mathrm{HCl}, 3 \mathrm{mM}$ $\mathrm{KCl}, 120 \mathrm{mM} \mathrm{NaCl}, \mathrm{pH}$ 7.4) to a concentration of $0.5-1.5 \mathrm{mg}$ protein $/ \mathrm{ml}$. Membranes $(100 \mu \mathrm{l}$ of the platelet membrane suspension) were incubated for $90 \mathrm{~min}$ at $4^{\circ} \mathrm{C}$ in $300 \mu \mathrm{l}$ of incubation buffer with $\left[{ }^{3} \mathrm{H}\right]$-imipramine (specific activity $49.3 \mathrm{Ci} / \mathrm{mmol}$, NEN), $\left[{ }^{3} \mathrm{H}\right]$-paroxetine (specific activity $28.5 \mathrm{Ci} / \mathrm{mmol}$, NEN), or $\left[{ }^{125} \mathrm{I}\right]$-lysergic acid diethylamide (LSD) (specific activity $2200 \mathrm{Ci} / \mathrm{mmol}, \mathrm{NEN}$ ) at various concentrations $(0.1,0.3,0.6,1.25,2.5,5$, and $10 \mathrm{nM})$. Nonspecific binding was determined by replacing $100 \mu \mathrm{l}$ of buffer with $100 \mu \mathrm{l}$ of desipramine $(100 \mu \mathrm{M})$, fluoxetine $(10 \mu \mathrm{M})$, or ketanserin $(1 \mu \mathrm{M})$. After incubation $(90 \mathrm{~min}$ at $4^{\circ} \mathrm{C}$ for $\left[{ }^{3} \mathrm{H}\right]$-imipramine, $2 \mathrm{~h}$ at $20^{\circ} \mathrm{C}$ for $\left[{ }^{3} \mathrm{H}\right]$-paroxetine, $2 \mathrm{~h}$ at $37^{\circ} \mathrm{C}$ for $\left.\left[{ }^{125} \mathrm{I}\right]-\mathrm{LSD}\right)$, the contents of each tube were diluted in $5 \mathrm{ml}$ of incubation buffer at $0^{\circ} \mathrm{C}$ and immediately filtered through Whatman GF/B glass fiber filters. The filters were washed three times with $5 \mathrm{ml}$ of incubation buffer and dried. Radioactivity was measured by liquid (tritiated ligands) or solid ([ $\left.\left.{ }^{125} \mathrm{I}\right]-\mathrm{LSD}\right)$ scintillation spectrometry. Specific binding was defined as the difference between total and nonspecific binding. The binding data were analyzed with the iterative nonlinear least-squares curve-fitting program, EBDA-ligand, and values for $B_{\max }$ and $K_{\mathrm{d}}$ were determined.

Inositol triphosphate. The platelet concentration of $\mathrm{IP}_{3}$ was measured radioimmunologically as described previously (Delorme et al, 2004).

\section{Genotyping}

Two polymorphisms in untranslated regions of the 5-HTT gene (SLC6A4) were investigated to explore the possible molecular mechanisms underlying serotonergic endophenotypes: a variable number of tandem repeats (VNTR) in intron 2, and an insertion/deletion in the promoter region (5-HTTLPR). The polymerase chain reaction (PCR) was performed with primers flanking the polymorphisms in the promoter and in intron 2 following protocols already published (Betancur et al, 2002).

\section{Statistical Analysis}

Since the observed distribution of several biochemical parameters was not normal in the different groups (OCD probands, unaffected relatives, and controls), intergroup comparisons were made with a nonparametric test, the Mann-Whitney $U$-test. The relationship between biochemical parameters and genotypes was analyzed with nonparametric analysis of variance, using the Kruskall-Wallis test. To study intrafamilial correlations, we used the Fisher intraclass correlation method with the biochemical parameters as continuous variables. This method involves the analysis of variance 'within families' $\left(s^{2} w\right)$ and 'between families' $\left(s^{2} b\right)$. The intraclass coefficient (ICC) is then calculated as

$$
\begin{aligned}
\text { ICC } & =\frac{s^{2} b-s^{2} w}{s^{2} b+\left(n_{0}-1\right) s^{2} w} \\
\text { with } n_{0} & =\frac{1}{a-1}\left[\sum^{a} n_{i}-\frac{\sum^{a} n_{i}^{2}}{\sum^{a} n_{i}}\right]
\end{aligned}
$$

with ' $a$ ' being the total number of families, and ' $n_{i}$ ' being the number of subjects in the families. If there is no aggregation of the trait within families, and if the trait is randomly distributed, then ICC $=0$. If the trait is distributed only within families, then the ICC is significantly different from 0 . All statistical analyses were performed with the aid of SPSS/PC + computer software.

\section{RESULTS}

\section{Traits Present in Affected Individuals}

To test if the peripheral serotonergic parameters studied were associated with the illness, the proband group and 
their respective sex- and age-matched controls were compared. As shown in Figure 1, OCD probands had lower whole blood 5-HT concentration $(p<0.001)$, reduced number of platelet 5 -HTT-binding sites $\left(\left[{ }^{3} \mathrm{H}\right]\right.$-imipramine $B_{\text {max }}, \quad p<0.05 ; \quad\left[{ }^{3} \mathrm{H}\right]$-paroxetine $\left.B_{\max }, \quad p<0.001\right)$, lower 5 -HTT-binding affinity $\left(\left[{ }^{3} \mathrm{H}\right]\right.$-paroxetine $\left.K_{\mathrm{d}}, p<0.001\right)$, and higher platelet $\mathrm{IP}_{3}$ content $(p<0.001)$ than controls (Figure 1). None of the other peripheral serotonergic parameters differed between OCD patients and controls. Similar results were obtained in the subgroup of drug-free OCD probands $(n=33)$ when compared to their respective sex- and age-matched controls: lower whole blood 5-HT level $(p<0.05)$, reduced number of platelet 5-HTT-binding sites $\left(\left[{ }^{3} \mathrm{H}\right]\right.$-paroxetine $\left.B_{\max }, p<0.001\right)$, reduced 5-HTTbinding affinity $\left(\left[{ }^{3} \mathrm{H}\right]\right.$-imipramine $K_{\mathrm{d}}, p<0.05$; $\left[{ }^{3} \mathrm{H}\right]$-paroxetine $\left.K_{\mathrm{d}}, p<0.05\right)$, and higher platelet $\mathrm{IP}_{3}$ content $(p<0.001)$ (Figure 1). In the subgroup of probands treated with 5-HT reuptake inhibitors $(n=15)$, we also observed analogous abnormalities of the peripheral serotonergic parameters (Figure 1). Although the dose, type, and efficacy of 5-HT reuptake inhibitors were not controlled in the subgroup of treated probands, these findings suggest that the observed biochemical abnormalities represent a trait, not influenced by illness state. Furthermore, no significant gender differences were found for any of the serotonergic parameters when comparing male and female OCD patients.

\section{Traits Present in Unaffected Relatives}

To test if the peripheral serotonergic abnormalities observed in OCD probands were also present in the unaffected parents, they were compared to their respective sex- and age-matched controls. The decrease in blood 5-HT content $(p<0.001)$, and in the number of 5-HTT-binding sites $\left(\left[{ }^{3} \mathrm{H}\right]\right.$-imipramine $B_{\max }, \quad p<0.001 ;\left[{ }^{3} \mathrm{H}\right]$-paroxetine $\left.B_{\max }, p<0.001\right)$, the lower 5-HTT-binding affinity $\left(\left[{ }^{3} \mathrm{H}\right]-\right.$ imipramine $\left.K_{\mathrm{d}}, p<0.001\right)$, and the increase in platelet $\mathrm{IP}_{3}$ content $(p<0.05)$ were also found in unaffected parents of OCD patients (Figure 1). In addition, 5- $\mathrm{HT}_{2 \mathrm{~A}}$ receptorbinding characteristics differed in relatives and controls, with an increase in $\left[{ }^{125} \mathrm{I}\right]-\mathrm{LSD} B_{\max }(p<0.001)$ and an increased affinity $(p<0.001)$ in the group of parents (Figure 1).

\section{Familial Aggregation of the Traits}

To test if the peripheral serotonergic abnormalities observed in OCD probands and their parents were aggregated in OCD families, the intrafamilial correlation was calculated in the subgroup of unaffected relatives who had a proband in the sample $(n=59)$. Only whole blood 5-HT concentration appeared aggregated within families $(\mathrm{ICC}=0.45, p<0.001)$. The intrafamilial correlation remained significant when examined in the subgroups composed of probands and their fathers $(n=24$, ICC $=0.37, p<0.02)$ or probands and their mothers $(n=35$, ICC $=0.53, p<0.001)$. No significant intrafamilial correlation was observed for any of the other biochemical parameters.
Relationship between Platelet Serotonergic Markers and Polymorphisms in the 5-HTT Gene

To test if two polymorphisms in the 5-HTT gene, a VNTR in intron 2 and 5-HTTLPR in the promoter region, could play a role in the peripheral serotonergic abnormalities observed in OCD probands and their unaffected parents, we studied the relationship between genotypes and biochemical variables. We did not observe any effect of the genotypes on whole blood 5-HT level, $K_{\mathrm{d}}$, or $B_{\max }$ of 5-HTT measured with $\left[{ }^{3} \mathrm{H}\right]$-paroxetine and $\left[{ }^{3} \mathrm{H}\right]$-imipramine (Table 2 ).

\section{DISCUSSION}

Abnormalities in peripheral serotonergic parameters were tested as putative trait markers for OCD by assessing a sample of OCD patients and their unaffected parents. Our results showing lower whole blood 5-HT concentration, fewer platelet number of 5-HTT, and higher platelet $\mathrm{IP}_{3}$ content in patients with OCD compared to controls had already been described previously by our group and others. In contrast, this is the first report to our knowledge to describe the same abnormalities in unaffected parents of OCD patients.

As OCD displays a complex pattern of inheritance (Nestadt et al, 2000a), these abnormalities of peripheral serotonergic parameters could represent the genetic liability of unaffected relatives of probands for the disorder. The highly significant intrafamilial correlation observed for whole blood 5-HT concentration suggests that the heritability of this marker is high. This is in agreement with a previous study, showing that whole blood 5-HT level had a heritability of 0.99 in a founder population (Ober et al, 2001). Thus, blood 5-HT level could be a heritable component in OCD families, and could be used as an alternative phenotype for OCD. Use of quantitative traits as an alternative phenotype is recognized to be of critical importance for understanding the genetic basis of complex diseases, and has been useful in facilitating gene identification in nonpsychiatric disorders. For example, the QT elongation on electrocardiogram was used to discover the genes underlying the long QT syndrome, characterized by syncope, ventricle arrhythmias, and sudden death (Keating and Sanguinetti, 2001). In the field of psychiatry, disturbances of P50 auditory evoked response and smooth pursuit eye movements are among the best established endophenotypes present in schizophrenic patients and their unaffected relatives, and linkage studies have already identified the loci involved in chromosome 15q (Freedman et $a l, 1997$ ) and 6p (Arolt et al, 1996), respectively. In OCD, stratification by 5-HT level could decrease genetic heterogeneity and increase power to identify susceptibility genes in association and linkage studies.

The reduction in whole blood 5-HT level in OCD patients had been described previously (Yaryura-Tobias et al, 1979), although other studies, including our own, reported that the baseline concentrations of 5-HT do not differ from those in controls (Cath et al, 2001; Delorme et al, 2004; Flament et al, 1987; Hanna et al, 1991; Insel and Winslow 1992). These discrepancies may be due to the small number of patients studied previously, the seasonal effects on 5-HT level (Brewerton et al, 1993), as well as the effects of sex, age, 

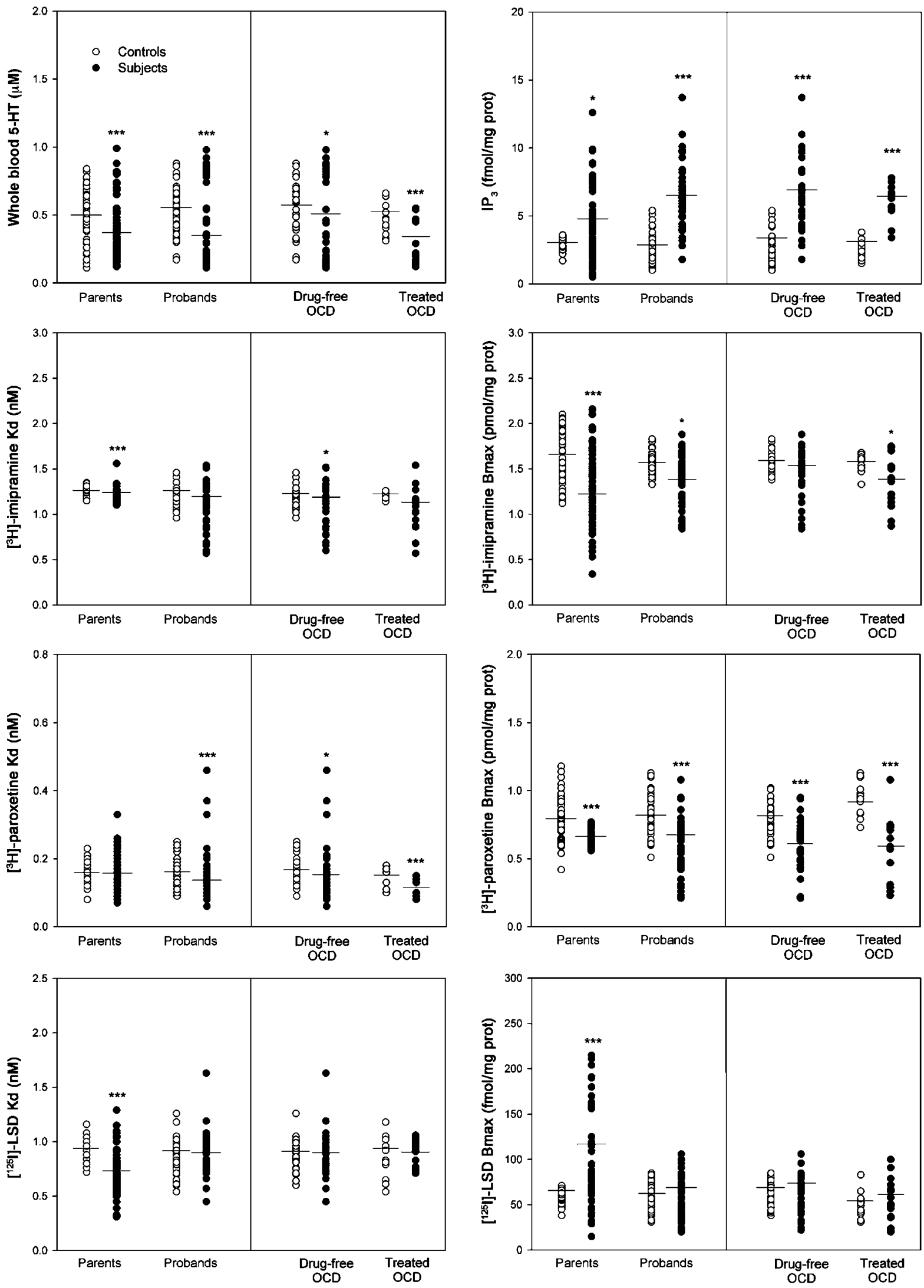

Figure I Whole blood 5-HT content, platelet 5-HT transporter-binding sites $\left(B_{\max }\right)$, and affinity $\left(K_{d}\right)$ measured with $\left[{ }^{3} H\right]$-imipramine and $\left[{ }^{3} H\right]$ paroxetine, platelet $5-\mathrm{HT}_{2 \mathrm{~A}}$ receptor-binding sites $\left(B_{\max }\right)$ and affinity $\left(K_{\mathrm{d}}\right)$ measured with $\left[{ }^{125} \mathrm{I}\right]-\mathrm{LSD}$, and platelet $\mathrm{IP}_{3}$ content in $O C D$ patients (all, $n=48$; drug-free, $n=33$; treated, $n=15)$, unaffected parents $(n=65)$, and their respective sex- and age-matched controls. Data represent distribution and mean of each parameter. $* p<0.05$, *** $<0.01$, **** $<0.001$, Mann-Whitney U-test. 
Table 2 Effect of the 5-HTTLPR and Intron 2VNTR Polymorphisms of the 5-HTT Gene on Whole Blood 5-HT level and $K_{d}$ or Bmax of 5 -HTT (Measured with $\left[{ }^{3} \mathrm{H}\right]$-Paroxetine and $\left[{ }^{3} \mathrm{H}\right]$-Imipramine) in a Sample of OCD Probands $(n=48)$, their Unaffected Parents $(n=65)$, and Controls $(n=1 \mid 3)$

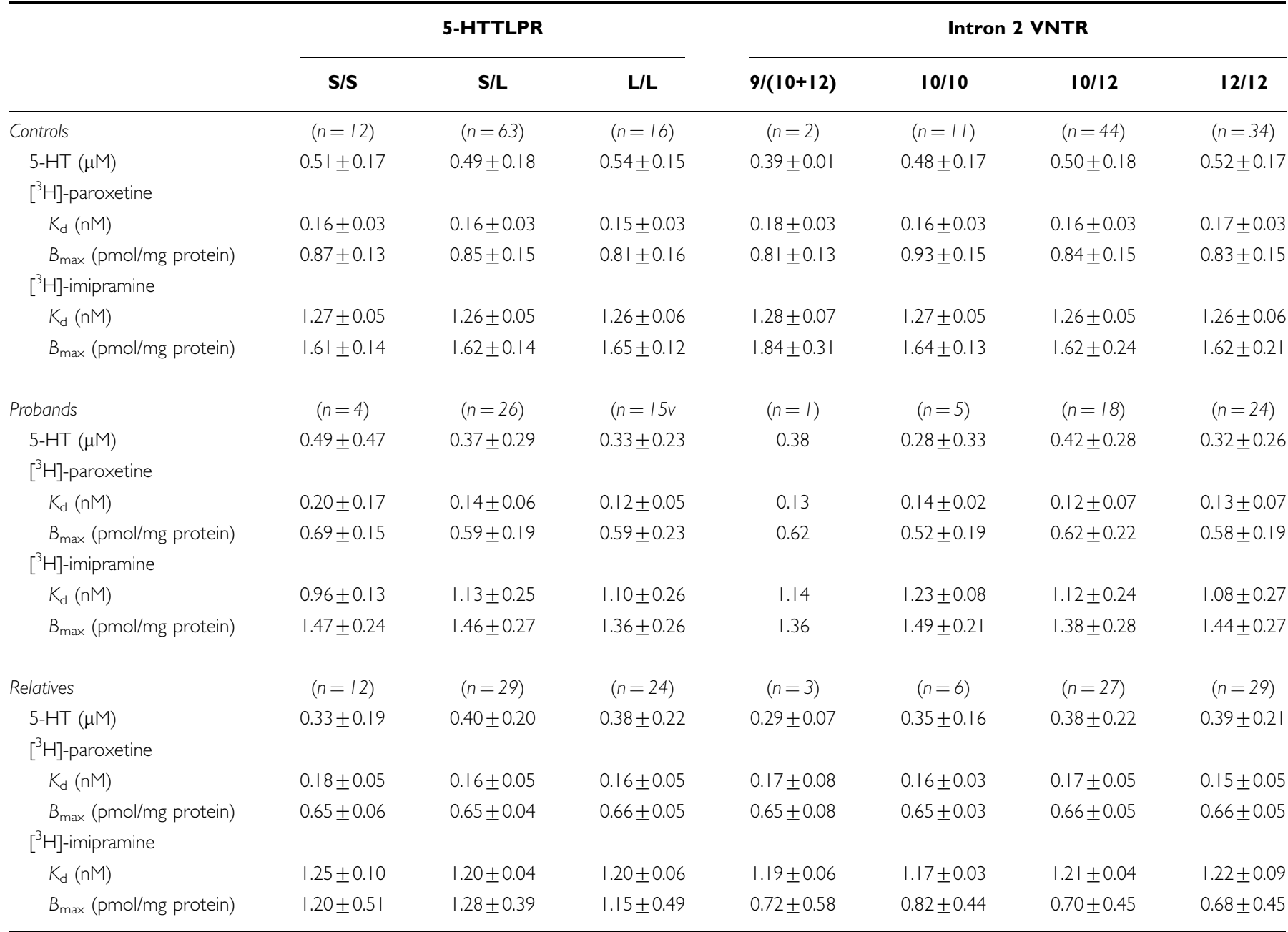

Data represent means \pm SD. Data were analyzed with nonparametric analysis of variance (Kruskall-Wallis test); no significant effect of the two polymorphisms was observed on any of the biochemical parameters studied.

and ethnic origin on 5-HT levels in the absence of matched controls. Furthermore, the diet poor in tryptophan and 5HT followed by all our subjects before blood sampling may have revealed the reduction in 5-HT levels in OCD patients, whereas the majority of previous studies apparently were not controlled for diet. Finally, the marked heterogeneity of whole blood 5-HT concentration in OCD patients raises the possibility that decreased 5-HT levels are present only in a subgroup of patients. In our sample, the distribution of whole blood 5-HT in unmedicated probands appears to be non-normally distributed, with two different subgroups: one $(n=10)$ with a high level of whole blood 5-HT $(0.85 \pm 0.07$ in OCD vs $0.49 \pm 0.23$ in their 10 respective controls, Mann-Whitney $U$ test, $Z=-3.02, p=0.02)$ and another $(n=23)$ with hyposerotonemia $(0.22 \pm 0.16$ in OCD vs $0.55 \pm 0.18$ in their 23 respective controls, Mann-Whitney $U$ test, $Z=-4.9, p=0.0001)$. Although these findings should be interpreted with caution given the limited sample size, they are in agreement with previous findings in the literature showing altered 5-HT levels only in a specific subgroup of patients. For instance, Cath et al (2001) showed that whole blood 5-HT content was reduced only in the subgroup of OCD patients with tics. Similarly, Hanna et al (1995) reported lower blood 5-HT concentrations in OCD patients with a concurrent diagnostic of disruptive behavior disorder. In our data set, the 5-HT level was not influenced by the presence or absence of tics, and there were no probands with disruptive behavior disorder.

As expected, the reduction in the number of 5-HTTbinding sites in OCD patients described in previous works (Bastani et al, 1991; Delorme et al, 2004; Marazziti et al, 1992, 1997, 1999; Sallee et al, 1996; Weizman et al, 1992) was confirmed in our study. This appears to be the most consistent abnormality of the peripheral serotonergic system observed to date in OCD. We also observed an increase in 5-HTT-binding affinity in OCD probands (decreased $\left[{ }^{3} \mathrm{H}\right]$-paroxetine $K_{\mathrm{d}}$ ) and their unaffected relatives (decreased $\left[{ }^{3} \mathrm{H}\right]$-imipramine $K_{\mathrm{d}}$ ) when compared to controls. Although these differences were statistically significant, their magnitude was quite small. Nevertheless, 
they could be helpful in the eventual elucidation of the biology of serotonergic endophenotypes and their relationship to genetics.

The elevated platelet $\mathrm{IP}_{3}$ content with unchanged 5- $\mathrm{HT}_{2 \mathrm{~A}}$ binding described as a preliminary finding in OCD probands (Delorme et al, 2004) was confirmed in this study in a larger sample. We previously suggested an increase in the intrinsic activity of the $5-\mathrm{HT}_{2 \mathrm{~A}}$ receptor in untreated patients to explain the increase in $\mathrm{IP}_{3}$ concentration in the absence of an increase in $5-\mathrm{HT}_{2 \mathrm{~A}}$ receptor number and affinity measured with [ $\left.{ }^{125} \mathrm{I}\right]-\mathrm{LSD}$ (Delorme et al, 2004). In contrast, unaffected relatives exhibited decreased $K_{\mathrm{d}}$ and increased $B_{\max }$ of $5-\mathrm{HT}_{2 \mathrm{~A}}$ receptors, associated with an increase in $\mathrm{IP}_{3}$ content. These results suggest that the increased activity of 5- $\mathrm{HT}_{2 \mathrm{~A}}$ receptors could be a physiological compensatory mechanism to the very low amount of 5-HT available for binding to its targets (Blier and de Montigny, 1999). This alteration of $5-\mathrm{HT}_{2 \mathrm{~A}}$-binding characteristics represents the main biochemical difference between OCD probands and their unaffected relatives among the serotonergic parameters studied, raising the possibility that $5-\mathrm{HT}_{2 \mathrm{~A}}$ receptor regulation could be determinant in the emergence of the OCD phenotype in genetically vulnerable individuals.

\section{Possible Molecular Mechanisms Underlying Serotonergic Endophenotypes}

The molecular mechanisms involved in the alteration of the serotonergic parameters in OCD patients and their parents remain to be elucidated. We did not observe an association between whole blood 5-HT level, $K_{\mathrm{d}}$, or $B_{\max }$ of 5-HTT (measured with $\left[{ }^{3} \mathrm{H}\right]$-paroxetine and $\left[{ }^{3} \mathrm{H}\right]$-imipramine) and two polymorphismsin the 5 -HTT gene, a 5 -HTTLPR in the promoter region and a VNTRin intron 2, which act in vitro as transcriptional regulators (Lesch et al, 1996; McKenzie and Quinn, 1999). The lack of association between 5-HT levels and 5-HTT polymorphisms is in accordance with previous reports in individuals suffering from autism (Betancur et al, 2002), alcoholism (Stoltenberg et al, 2002), or in healthy subjects (Greenberg et al, 1998). However, the possibility that other polymorphisms within regulatory or coding sequences at the 5-HTT locus could be more directly linked to the low blood 5-HT level observed in OCD patients cannot be excluded. Recently, a rare mutation in the 5-HTT gene coding region, Ile425Val, was reported in two unrelated families with OCD (Ozaki et al, 2003). However, analysis of the mutant transporter in heterologous cells revealed a two-fold increase in uptake activity (Kilic et al, 2003), which would result in increased platelet 5-HT level.

Alternatively, alterations in post-translational processing of 5-HTT protein could be responsible for the observed effects. In particular, phosphorylation by protein-kinase $\mathrm{C}$ profoundly affects 5-HTT function by inducing 5-HTT internalization (Ramamoorthy and Blakely, 1999). Increased phosphorylation could directly decrease the number of active 5-HTT molecules at the cell surface, and could account for the reduced number of platelet 5-HTT-binding sites and the low whole blood 5-HT concentration found in OCD probands and in their unaffected parents in this study. Interestingly, an increase in platelet protein-kinase C activity has been reported in drug-free OCD patients (Marazziti et al, 2000), supporting this hypothesis.

It is also possible that other genes might be involved in the regulation of 5-HT levels. A recent genome-wide association study in a founder population suggested that the $\beta 3$ integrin gene on $17 \mathrm{q} 21$ could be an important quantitative trait locus for whole blood 5-HT (Weiss et al, 2004).

Finally, we did not observe an association between a polymorphism in the $5-\mathrm{HT}_{2 \mathrm{~A}}$ receptor gene promoter $(1438 \mathrm{G} / \mathrm{A})$ and $5-\mathrm{HT}_{2 \mathrm{~A}}$ receptor-binding characteristics or $\mathrm{IP}_{3}$ levels in patients with OCD or their unaffected parents (data not shown). Although endophenotypes would ideally involve single genes, the possibility that they have a polygenic basis cannot be discarded at present. In addition, the origin of these alterations may be epigenetic or multifactorial.

\section{Diagnostic and Familial Specificity}

The decrease in whole blood 5-HT and 5-HTT binding are not unique to persons with OCD or at risk for developing such disorder, since these disturbances have also been observed in patients with affective disorders (Cleare, 1997; Alvarez et al, 1999) and in their unaffected relatives (Leboyer et al, 1999). Moreover, increased $\mathrm{IP}_{3}$ concentration has been reported in patients with unipolar depression (Alvarez et al, 1999). The lack of diagnostic and familial specificity of these findings could be interpreted as an indication of shared genetic factors in OCD and affective disorders. Recently, Nestadt et al (2003) reinforced the hypothesis of a shared etiopathogenic background by using latent class analysis to identify OCD-related subgroups based on comorbidity. They observed that patients with OCD and major depressive disorder appear to constitute a well-defined subgroup. Thus, the decreased whole blood 5HT level and 5-HTT function associated with the increased $\mathrm{IP}_{3}$ level could add a nonspecific disturbance to the more specific genetic and nongenetic causes of both disorders, thereby increasing the disease risk in the sense of a threshold model. Alternatively, it could suggest that there are specific interactions of the putative genes involved in these disturbances with other causal genes resulting in the emergence of subtypes of OCD and affective disorders.

\section{Limitations}

Several limitations of this study should be noted. First, a general problem for the interpretation of differences in affected subjects is the fact that medication may interfere with the outcome. Here, we showed that all the alterations of the serotonergic system observed in OCD probands were also present in the subgroup of drug-free patients. The specificity of these findings is further supported by the presence of a similar serotonergic dysfunction in the unaffected parents of OCD patients. Therefore, our results suggest that lower whole blood 5-HT concentration, fewer platelet number of 5-HTT, and higher platelet $\mathrm{IP}_{3}$ content may be state as well as trait markers. Second, although there is a remarkable stability of whole blood 5-HT level over time in normoserotonergic adult controls (Yuwiler et al, 1970), the long-term alteration of peripheral serotonergic markers 
in OCD probands and their relatives remains to be proved. Finally, except for whole blood 5-HT concentration, none of the other serotonergic parameters showed a positive intrafamilial correlation. The lack of familial correlation for peripheral markers that were similarly altered in OCD patients and their parents (decreased number of 5-HTTbinding sites labeled with $\left[{ }^{3} \mathrm{H}\right]$-paroxetine and $\left[{ }^{3} \mathrm{H}\right]$ imipramine, and increased platelet $\mathrm{IP}_{3}$ content) suggests that their inheritance may be complex, with incomplete penetrance and/or influenced by environmental factors. It is also possible that the failure to find positive intrafamilial correlations is due to the limited sample size and that much larger study groups are needed. Whole blood 5-HT concentration depends mainly on the activity of 5-HTT and 5-HT2A receptors, and on the storage capacity of platelets (Da Prada et al, 1988). Therefore, the intrafamilial correlation observed for whole blood 5-HT could result from the cumulative effect of genetic factors that underlie each of these parameters.

\section{Conclusion}

The present findings show for the first time the presence of lower whole blood 5-HT concentration, decreased platelet 5HTT $B_{\max }$, and higher platelet $\mathrm{IP}_{3}$ content in the unaffected parents of OCD patients, which could represent endophenotypes in this disorder. Whether these serotonergic disturbances represent true biological markers of the genetic susceptibility to OCD awaits replication in others samples. These abnormalities might lead to the identification of individuals at risk for OCD, and, consequently, increase the power of genetic analyses by identifying all the members of the pedigree carrying vulnerability factors. By improving the phenotypic characterization of patients and unaffected relatives, these results may contribute to the identification of more homogeneous subgroups and yield insights into the neurobiological mechanisms involved in OCD.

\section{ACKNOWLEDGEMENTS}

We thank the patients and their families who made this research possible. We declare no conflicts of interest. This research was supported by INSERM (National Institute of Health and Medical Research). RD was supported by a fellowship from Fondation pour la Recherche Médicale and NC by a fellowship from INSERM.

\section{REFERENCES}

Alsobrook IJ, Leckman JF, Goodman WK, Rasmussen SA, Pauls DL (1999). Segregation analysis of obsessive-compulsive disorder using symptom-based factor scores. Am J Med Genet 88: 669-675.

Alvarez JC, Gluck N, Arnulf I, Quintin P, Leboyer M, Pecquery R et al (1999). Decreased platelet serotonin transporter sites and increased platelet inositol triphosphate levels in patients with unipolar depression: effects of clomipramine and fluoxetine. Clin Pharmacol Ther 66: 617-624.

Arolt V, Lencer R, Nolte A, Muller-Myhsok B, Purmann S, Schurmann M et al (1996). Eye tracking dysfunction is a putative phenotypic susceptibility marker of schizophrenia and maps to a locus on chromosome $6 \mathrm{p}$ in families with multiple occurrence of the disease. Am J Med Genet 67: 564-579.

Barr LC, Goodman WK, Price LH, McDougle CJ, Charney DS (1992). The serotonin hypothesis of obsessive compulsive disorder: implications of pharmacologic challenge studies. J Clin Psychiatry 53(Suppl): 17-28.

Bastani B, Arora RC, Meltzer HY (1991). Serotonin uptake and imipramine binding in the blood platelets of obsessivecompulsive disorder patients. Biol Psychiatry 30: 131-139.

Betancur C, Corbex M, Spielewoy C, Philippe A, Laplanche JL, Launay JM et al (2002). Serotonin transporter gene polymorphisms and hyperserotonemia in autistic disorder. Mol Psychiatry 7: 67-71.

Black DW, Kelly M, Myers C, Noyes Jr R (1990). Tritiated imipramine binding in obsessive-compulsive volunteers and psychiatrically normal controls. Biol Psychiatry 27: 319-327.

Blier P, de Montigny C (1999). Serotonin and drug-induced therapeutic responses in major depression, obsessive-compulsive and panic disorders. Neuropsychopharmacology 21: 91S-98S.

Brewerton TD, Flament MF, Rapoport JL, Murphy DL (1993). Seasonal effects on platelet 5-HT content in patients with OCD and controls. Arch Gen Psychiatry 50: 409.

Cath DC, Spinhoven P, Landman AD, van Kempen GM (2001). Psychopathology and personality characteristics in relation to blood serotonin in Tourette's syndrome and obsessive-compulsive disorder. J Psychopharmacol 15: 111-119.

Cleare AJ (1997). Reduced whole blood serotonin in major depression. Depress Anxiety 5: 108-111.

Da Prada M, Cesura AM, Launay JM, Richards JG (1988). Platelets as a model for neurones? Experientia 44: 115-126.

Delorme R, Chabane N, Callebert J, Falissard B, Mouren-Simeoni MC, Rouillon F et al (2004). Platelet serotonergic predictors of clinical improvement in obsessive compulsive disorder. J Clin Psychopharmacol 24: 1-6.

Flament MF, Rapoport JL, Murphy DL, Berg CJ, Lake CR (1987). Biochemical changes during clomipramine treatment of childhood obsessive-compulsive disorder. Arch Gen Psychiatry 44: 219-225.

Freedman R, Coon H, Myles-Worsley M, Orr-Urtreger A, Olincy A, Davis A et al (1997). Linkage of a neurophysiological deficit in schizophrenia to a chromosome 15 locus. Proc Natl Acad Sci USA 94: 587-592.

Goodman WK, Price LH, Rasmussen SA, Mazure C, Fleischmann RL, Hill CL et al (1989). The Yale-Brown Obsessive Compulsive Scale. I. Development, use, and reliability. Arch Gen Psychiatry 46: 1006-1011.

Gottesman II, Gould TD (2003). The endophenotype concept in psychiatry: etymology and strategic intentions. Am J Psychiatry 160: 636-645.

Greenberg BD, McMahon FJ, Murphy DL (1998). Serotonin transporter candidate gene studies in affective disorders and personality: promises and potential pitfalls. Mol Psychiatry 3: 186-189.

Hanna GL, Veenstra-VanderWeele J, Cox NJ, Boehnke M, Himle JA, Curtis GC et al (2002). Genome-wide linkage analysis of families with obsessive-compulsive disorder ascertained through pediatric probands. Am J Med Genet 114: 541-552.

Hanna GL, Yuwiler A, Cantwell DP (1991). Whole blood serotonin in juvenile obsessive-compulsive disorder. Biol Psychiatry 29: 738-744.

Hanna GL, Yuwiler A, Cantwell DP (1993). Whole blood serotonin during clomipramine treatment of juvenile obsessive-compulsive disorder. J Child Adolesc Psychopharmacol 3: 223-229.

Hanna GL, Yuwiler A, Coates JK (1995). Whole blood serotonin and disruptive behaviors in juvenile obsessive-compulsive disorder. J Am Acad Child Adolesc Psychiatry 34: 28-35. 
Insel TR, Winslow JT (1992). Neurobiology of obsessive compulsive disorder. Psychiatr Clin North Am 15: 813-824.

Jonnal AH, Gardner CO, Prescott CA, Kendler KS (2000). Obsessive and compulsive symptoms in a general population sample of female twins. Am J Med Genet 96: 791-796.

Keating MT, Sanguinetti MC (2001). Molecular and cellular mechanisms of cardiac arrhythmias. Cell 104: 569-580.

Kilic F, Murphy DL, Rudnick G (2003). A human serotonin transporter mutation causes constitutive activation of transport activity. Mol Pharmacol 64: 440-446.

Leboyer M (2003). Searching for alternative phenotypes in psychiatric genetics. Methods Mol Med 77: 145-161.

Leboyer M, Bellivier F, Nosten-Bertrand M, Jouvent R, Pauls D, Mallet J (1998). Psychiatric genetics: search for phenotypes. Trends Neurosci 21: 102-105.

Leboyer M, Quintin P, Manivet P, Varoquaux O, Allilaire JF, Launay JM (1999). Decreased serotonin transporter binding in unaffected relatives of manic depressive patients. Biol Psychiatry 46: $1703-1706$.

Lesch KP, Bengel D, Heils A, Sabol SZ, Greenberg BD, Petri S et al (1996). Association of anxiety-related traits with a polymorphism in the serotonin transporter gene regulatory region. Science 274: 1527-1531.

Marazziti D, Akiskal HS, Rossi A, Cassano GB (1999). Alteration of the platelet serotonin transporter in romantic love. Psychol Med 29: 741-745.

Marazziti D, Hollander E, Lensi P, Ravagli S, Cassano GB (1992). Peripheral markers of serotonin and dopamine function in obsessive-compulsive disorder. Psychiatry Res 42: 41-51.

Marazziti D, Masala I, Rossi A, Hollander E, Presta S, Giannaccini $\mathrm{G}$ et al (2000). Increased inhibitory activity of protein kinase C on the serotonin transporter in OCD. Neuropsychobiology 41: 171-177.

Marazziti D, Pfanner C, Palego L, Gemignani A, Milanfranchi A, Ravagli S et al (1997). Changes in platelet markers of obsessivecompulsive patients during a double-blind trial of fluvoxamine versus clomipramine. Pharmacopsychiatry 30: 245-249.

Marek GJ, Carpenter LL, McDougle CJ, Price LH (2003). Synergistic action of 5-HT2A antagonists and selective serotonin reuptake inhibitors in neuropsychiatric disorders. Neuropsychopharmacology 28: 402-412.

Matuchansky C, Launay JM (1995). Serotonin, catecholamines, and spontaneous midgut carcinoid flush: plasma studies from flushing and nonflushing sites. Gastroenterology 108: 743-751.

McDougle CJ, Epperson CN, Pelton GH, Wasylink S, Price LH (2000). A double-blind, placebo-controlled study of risperidone addition in serotonin reuptake inhibitor-refractory obsessive-compulsive disorder. Arch Gen Psychiatry 57: 794-801.

McKenzie A, Quinn J (1999). A serotonin transporter gene intron 2 polymorphic region, correlated with affective disorders, has allele-dependent differential enhancer-like properties in the mouse embryo. Proc Natl Acad Sci USA 96: 15251-15255.

Nestadt G, Addington A, Samuels J, Liang KY, Bienvenu OJ, Riddle $M$ et al (2003). The identification of OCD-related subgroups based on comorbidity. Biol Psychiatry 53: 914-920.

Nestadt G, Lan T, Samuels J, Riddle M, Bienvenu III OJ, Liang KY et al (2000a). Complex segregation analysis provides compelling evidence for a major gene underlying obsessive-compulsive disorder and for heterogeneity by sex. Am J Hum Genet 67: 1611-1616.

Nestadt G, Samuels J, Riddle M, Bienvenu III OJ, Liang KY, LaBuda $\mathrm{M}$ et al (2000b). A family study of obsessive-compulsive disorder. Arch Gen Psychiatry 57: 358-363.

Nurnberger Jr JI, Blehar MC, Kaufmann CA, York-Cooler C, Simpson SG, Harkavy-Friedman J et al (1994). Diagnostic interview for genetic studies. Rationale, unique features, and training. NIMH Genetics Initiative. Arch Gen Psychiatry 51: 849-859; discussion 863-864.

Ober C, Abney M, McPeek MS (2001). The genetic dissection of complex traits in a founder population. Am J Hum Genet 69: 1068-1079.

Orvaschel H, Puig-Antich J, Chambers W, Tabrizi MA, Johnson R (1982). Retrospective assessment of prepubertal major depression with the Kiddie-SADS-e. J Am Acad Child Psychiatry 21: 392-397.

Ozaki N, Goldman D, Kaye WH, Plotnicov K, Greenberg BD, Lappalainen $\mathrm{J}$ et al (2003). Serotonin transporter missense mutation associated with a complex neuropsychiatric phenotype. Mol Psychiatry 8: 933-936.

Pauls DL, Alsobrook II JP, Goodman W, Rasmussen S, Leckman JF (1995). A family study of obsessive-compulsive disorder. Am J Psychiatry 152: 76-84.

Ramamoorthy S, Blakely RD (1999). Phosphorylation and sequestration of serotonin transporters differentially modulated by psychostimulants. Science 285: 763-766.

Sallee FR, Richman H, Beach K, Sethuraman G, Nesbitt L (1996). Platelet serotonin transporter in children and adolescents with obsessive-compulsive disorder or Tourette's syndrome. J Am Acad Child Adolesc Psychiatry 35: 1647-1656.

Stoltenberg SF, Twitchell GR, Hanna GL, Cook EH, Fitzgerald HE, Zucker RA et al (2002). Serotonin transporter promoter polymorphism, peripheral indexes of serotonin function, and personality measures in families with alcoholism. Am J Med Genet 114: 230-234.

Weiss LA, Veenstra-Vanderweele J, Newman DL, Kim SJ, Dytch H, McPeek MS et al (2004). Genome-wide association study identifies ITGB3 as a QTL for whole blood serotonin. Eur $J$ Hum Genet 12: 949-954.

Weissman MM, Bland RC, Canino GJ, Greenwald S, Hwu HG, Lee CK et al (1994). The cross national epidemiology of obsessive compulsive disorder. The Cross National Collaborative Group. J Clin Psychiatry 55(Suppl): 5-10.

Weizman A, Mandel A, Barber Y, Weitz R, Cohen A, Mester R, Rehavi M (1992). Decreased platelet imipramine binding in Tourette syndrome children with obsessive-compulsive disorder. Biol Psychiatry 31: 705-711.

Willour VL, Yao Shugart Y, Samuels J, Grados M, Cullen B, Bienvenu III OJ et al (2004). Replication study supports evidence for linkage to 9p24 in obsessive-compulsive disorder. Am J Hum Genet 75: 508-513.

Yaryura-Tobias JA, Neziroglu F, Bhagavan HN (1979). Obsessivecompulsive disorders: a serotonergic hypothesis. In: Saletu B, Berner P, Hollister L (eds). Neuropsychopharmacology: Proceedings of the 11th Congress of the CNIP. Pergamon: Oxford, UK. pp 117-125.

Yuwiler A, Plotkin S, Geller E, Ritvo ER (1970). A rapid accurate procedure for the determination of serotonin in whole human blood. Biochem Med 3: 426-431. 